\title{
Toxoplasma gondii in semen of experimentally infected swine ${ }^{1}$
}

\author{
Anderson B. Moura ${ }^{2,3^{\prime \prime}}$, Alvimar J. Costa ${ }^{3}$, Sérgio Jordão Filho ${ }^{3}$, Beatriz B. Paim ${ }^{3}$, \\ Fernanda R. Pinto ${ }^{3}$ and Daniela C. Di Mauro ${ }^{3}$
}

\begin{abstract}
Moura A.B., Costa A.J., Jordão Filho S., Paim B.B., Pinto F.R. \& Di Mauro D.C. 2007. Toxoplasma gondii in semen of experimentally infected swine. Pesquisa Veterinária Brasileira 27(10):430-434. Centro de Pesquisas em Sanidade Animal, Faculdade de Ciências Agrárias e Veterinárias, Universidade Estadual Paulista, Jaboticabal, SP 14884-900, Brazil. E-mail: a2abm@cav.udesc.br

Eight reproductive boars were divided into three groups and inoculated with Toxoplasma gondii [GI $(\mathrm{n}=3) 1.5 \times 10^{4}$ oocysts strain P; GII $(\mathrm{n}=3) 1.0 \times 10^{6}$ tachyzoites strain $\mathrm{RH}$; and GIII $(n=2)$ non-inoculated control]. Clinical, hematological, parasitemia and serological tests and studies of the parasite in the semen through bioassay and PCR, and in reproductive organs (Bioassay and immunohistochemical analyses) were conducted to evaluate the toxoplasmic infection. Blood and semen were collected on day $-2,-1,1,3,5,7,9,11,14$ and weekly up to 84 days post-inoculation (DPI). No clinical or hematimetric alteration was observed in the boars. Parasitemia was detected in one boar inoculated with oocysts at the $7^{\text {th }}$ DPI and in another boar infected with tachyzoites (GII) at the $3^{\text {rd }}$ and $49^{\text {th }}$ DPI. Serological tests revealed antibodies against $T$. gondii in animals inoculated with oocysts or tachyzoites at the $7^{\text {th }}$ DPI with dilutions of 1:256 and 1:64, which reached peaks of 1:4096 at day 11 and 9, respectively. The bioassays revealed the presence of the parasite in semen samples of a boar inoculated with oocysts (GI) at 3, 49 and 56 DPI and from two boars infected with tachyzoites (GII), one animal at 5 and two animals at 49 days DPI. Mice inoculated with semen from the control group (GIII) remained serologically negative. PCR analysis showed T. gondii DNA in the semen of Boar 1 and Boar 3 inoculated with tachyzoites and oocysts, respectively. The immunohistochemical tests showed T. gondii in the reproductive organs of Boar 1 and Boar 2, inoculated with tachyzoites and oocysts, respectively. These findings suggest the possible occurrence of venereal transmission of $T$. gondii in swine.
\end{abstract}

INDEX TERMS: Toxoplasmosis, swine, semen, PCR, bioassays.

RESUMO-- [Toxoplasma gondii no sêmen de suínos experimentalmente infectados.] Oito reprodutores suínos foram divididos em três grupos e inoculados com Toxoplasma gondii [GI $(\mathrm{n}=3) 1.5 \times 10^{4}$ oocistos cepa P; GII $(\mathrm{n}=3) 1.0 \times 10^{6}$ taquizoítos cepa RH, e GIII $(\mathrm{n}=2)$ controle, não inoculados]. Exa-

\footnotetext{
${ }^{1}$ Received on August 3, 2006.

Accepted for publication on June 4, 2007.

Part of the Doctor Dissertation in Veterinary Medicine (Animal Pathology) of the first author, Faculdade de Ciências Agrárias e Veterinárias (FCAV), Universidade Estadual Paulista (Unesp), Campus de Jaboticabal, SP.

${ }^{2}$ Departamento de Medicina Veterinária Preventiva e Tecnologia (DMVPT), Centro de Ciências Agroveterinárias (CAV), Universidade do Estado de Santa Catarina (UDESC), Avenida Luiz de Camões 2090, Lages, SC 88520-000, Brazil. *Corresponding author: a2abm@cav.udesc.br

${ }^{3}$ Centro de Pesquisas em Sanidade Animal, FCAV, Unesp-Jaboticabal, Via de Acesso Prof. Paulo Donato Castellane s/n, Jaboticabal, SP 14884-900, Brazil.
}

mes clínicos, hematológicos, de parasitemia e sorológicos foram realizados para avaliar a infecção toxoplásmica. Pesquisa do parasito no sêmen, por meio do bioensaio e pela técnica da PCR, e em órgãos do sistema reprodutor (bioensaio e imunohistoquímica) foi realizada. Sangue e sêmen foram colhidos nos dias $-2,-1,1,3,5,7,9,11,14$, e semanalmente até o $84^{\circ}$ dia pós-infecção (DPI). Nenhuma alteração clínica ou hematimétrica foi observadda nos animais. Parasitemia foi detectada em um animal inoculado com oocistos no $7^{\circ} \mathrm{DPI}$ e em outro inoculado com taquizó́tos (GII) nos $3^{\circ}$ e $49^{\circ}$ DPI. A sorologia revelou a presença de anticorpos contra $T$. gondii nos animais inoculados com oocistos ou taquizoítos no $7^{\circ}$ DPI com títulos de 1:256 e 1:64, que atingiram picos de 1:4096 nos dias 11 e 9 , respectivamente. $O$ bioensaio revelou a presença do parasita em amostras seminais de um animal inoculado com oocistos $(\mathrm{GI})$ nos $3^{\circ}, 49^{\circ}$ e $56^{\circ} \mathrm{DPI}$, e de dois animais 
infectados com taquizoítos (GII), um deles no $5^{\circ}$ DPI e os dois ao $49^{\circ}$ DPI. Pela PCR, o DNA de T. gondii foi detectado no sêmen dos Suínos 1 e 3 inoculados com taquizoítos e oocistos, respectivamente. A imunohistoquímica revelou $T$. gondii em órgão do aparelho reprodutor dos Suínos 1 e 2, inoculados com taquizoítos e oocistos, respectivamente. Esses achados sugerem a possibilidade da ocorrência da transmissão venérea do $T$. gondii em suínos.

TERMOS DE INDEXAÇÃO: Toxoplasmose, suíno, sêmen, PCR, bioprova.

\section{INTRODUCTION}

Animal toxoplasmosis is a parasitic disease of great importance since the infected animals can become a direct or indirect source of infection for human beings. Reproductive disorders such as abortion and stillborn or weak neonates, which lead to death, cause considerable economic losses (Vidotto \& Costa 1987).

Among production animals, swine are the most common animals that harbor Toxoplasma gondii (Dubey \& Thulliez 1993, Silva et al. 2003). The pork-infected meat is considered the main source of toxoplasmosis transmission to humans in the USA and probably in several other countries (Gamble 1997). In swine, $T$. gondii can be viable for more than a year (Dubey 1994) or indefinitely over the entire life span (Tenter et al. 2000) as cysts in muscle tissues. Oocysts eliminated by cats are the main source of infection for most herbivores and swine as observed by Assadi-Rad et al. (1995). Since swine are omnivores, they can also be infected by the ingestion of tissue cysts found in muscle tissues of rodents and birds. Besides these common mechanisms of infection, swine can be infected with T. gondii through transplacental transmission (Dubey \& Urban 1990). Toxoplasmosis has been the subject of continuous investigation in the swine industry mainly because of the pathogenesis that it causes in the reproductive tract of females associated with obstetric disorders (Damriyasa et al. 2004).

Although several studies have isolated T. gondii from semen of sheep (Spence et al. 1978, Teale et al. 1982, Aganga et al. 1988), goats (Dubey \& Sharma 1980) and cattle (Scarpelli 2001), there is no literature to our knowledge that has shown the detection of T. gondii in the semen of swine, which is the aim of this paper.

\section{MATERIALS AND METHODS}

The strains "P" (Jamra \& Vieira 1991) and "RH" (Sabin 1941) of Toxplasma gondii were used in the present study, stored at the "Centro de Pesquisas em Sanidade Animal" (CPPAR), Faculdade de Ciências Agrárias e Veterinárias (FCAV), São Paulo State University (Unesp), Jaboticabal, SP, Brazil.

Eight hybrid 11 to 12-month-old boars (Large White x Landrace), serologically negative for $T$. gondii by indirect immunofluorescent antibody test - IIFA (Camargo 1964), were selected for the study. The animals were identified, randomized, divided into three groups and inoculated with $T$. gondii, as follows: $\mathrm{GI}(\mathrm{n}=3), 1.5 \times 10^{4}$ oocysts strain P; GII $(\mathrm{n}=3), 1.0 \times 10^{6}$ tachyzoites strain $\mathrm{RH}$; and GIII $(\mathrm{n}=2)$, control non-inoculated.
All animals were kept in individual stalls. Water and food were given ad libitum. Feces from animals inoculated with oocysts were removed and treated with a disinfectant daily for seven consecutive days after infection. Serological tests for brucellosis and leptospirosis were conducted prior to inoculation and monthly during the entire experiment.

Parasitemia was determined in mice according to the technique described by Costa et al. (1977).

Antibodies against T. gondii were investigated through IIFA. Serum samples were collected from all experimental animals two days before inoculation, on 1, 3, 5, 7, 9, 11, $14 \mathrm{DPI}$, and weekly until the end of the trial.

Semen from the eight boars tested were obtained through ejaculation two days before inoculation, and on days 1, 3, 5, 7, 9, 11, 14 and weekly until the $84^{\text {th }}$ DPI using the gloved-hand technique, according to Wentz \& Bortolozzo (1998), with the exception of Boar 5 (after the $61^{\text {st }} \mathrm{DPI}$ ), Boar 6 (after the $28^{\text {th }} \mathrm{DPI}$ ), and Boar 8 (on the $\left.35^{\text {th }} \mathrm{DPI}\right)$.

T. gondii was isolated from semen samples (from all fractions) collected using the modified methodology of Teale et al. (1982).

A gene fragment $B_{1}(194 \mathrm{bp})$ from $T$. gondii was amplified from semen samples utilizing the primers 5'-GGAACTGCATCCGTTCA TGAG-3' (B1 ${ }_{1}$ ) and 5'TCTTTAAAGCGTTCGTGGTC-3' (B1 $\left.1_{2}\right)$, according to Fuentes et al. (1996). Serial dilutions of tachyzoites of $T$. gondii (strain RH) were conducted by utilizing PBS buffer or semen. An aliquot of $100 \mu \mathrm{L}$ of the initial dilution of $1.0 \times 10^{7}$ tachyzoites $/ \mathrm{mL}$ was added to $900 \mathrm{~mL}$ of PBS buffer or semen and diluted to $10^{6}, 10^{5}$, $10^{4}, 10^{3}, 10^{2}, 10^{1}$ and $10^{0}$ parasites per $\mathrm{mL}$. All samples were stored at $-20^{\circ} \mathrm{C}$ prior to DNA extraction. DNA of $T$. gondii from the serial dilutions in PBS (PCR positive control) and from the boar semen was extracted according to Sambrook et al. (1989).

Tissue samples from the reproductive tract (testicles, epididymes and seminal vesicles) were collected for bioassay and immunohistochemical analyses (Kit LSAB/HRP, Dako, USA) (Guesdon et al. 1979).

\section{RESULTS AND DISCUSSION}

Toxoplasmic infection of reproductive boars was confirmed by parasitemia and seroconversion in the inoculated animals used in this study. A low frequency of parasitemic outbreak found in this study might also be related to the virulence of the strains used and associated with the intermittency of parasitemia (Hitt \& Felice 1992). In the case of tachyzoites (strain RH), Giraldi et al. (1996) found parasitemia in 6\% (5 of 30 ) of the swine carriers of congenital toxoplasmosis. Costa (1982) evaluated toxoplasmic re-infection (strain N) in swine previously inoculated with the BV strain and found parasitemia in all animals from the experiment only up to the $12^{\text {th }}$ day post-first inoculation (BV strain).

The experimental infection of swine with $T$. gondii initiated a fast immunological response with the detection of antibodies beginning at the $7^{\text {th }}$ DPI. This early humoral response was also reported by D’Angelino \& Ishizuka (1986), although these authors stated that this was caused exclusively by tachyzoites.

The IgG curve determined in this study initiated on the $5^{\text {th }}$ DPI (Boar 9 with a titer of 1:16) and reached peaks of 1:4096 on the $9^{\text {th }}$ and 11 DPI in experimentally inoculated animals with tachyzoites and oocysts, respectively (Table 1). A gradual decrease in the swine humoral immune response started on 
Table 1. Results of Indirect Immunofluorescence Antibody test (IIFA) in sera of boars experimentally inoculated with tachyzoites or oocysts of Toxoplasma gondii

\begin{tabular}{|c|c|c|c|c|c|c|c|c|}
\hline \multirow{3}{*}{$\begin{array}{c}\text { Days after } \\
\text { inoculation } \\
1\end{array}$} & \multicolumn{8}{|c|}{ Reciprocal of titers in boars } \\
\hline & \multicolumn{3}{|c|}{$\begin{array}{l}\text { Inoculated with } \\
\text { tachyzoites }\end{array}$} & \multicolumn{3}{|c|}{$\begin{array}{l}\text { Inoculated with } \\
\text { oocysts }\end{array}$} & \multicolumn{2}{|c|}{ Control } \\
\hline & 4 & 9 & 2 & 3 & 5 & 6 & 8 & \\
\hline-2 & - & - & - & - & - & - & $-\mathrm{a}$ & - \\
\hline-1 & - & - & - & - & - & - & - & - \\
\hline 1 & - & - & - & - & - & - & - & - \\
\hline 3 & - & - & - & - & - & - & - & - \\
\hline 5 & - & - & 16 & - & - & - & - & - \\
\hline 7 & 16 & 64 & - & 16 & - & 256 & - & - \\
\hline 9 & 1024 & 4096 & 1024 & 256 & 1024 & 1024 & - & - \\
\hline 11 & 256 & 4096 & 4096 & 256 & 1024 & 4096 & - & - \\
\hline 14 & 4096 & 1024 & 4096 & 1024 & 1024 & 4096 & - & - \\
\hline 21 & 4096 & 4096 & 1024 & 64 & 1024 & 4096 & - & - \\
\hline 28 & 256 & 4096 & 256 & 1024 & 4096 & 256 & - & - \\
\hline 35 & 256 & 4096 & 256 & 16 & 64 & 1024 & - & - \\
\hline 42 & 256 & 256 & 4096 & 64 & 1024 & 4096 & ND & - \\
\hline 49 & 4096 & 1024 & 256 & 16 & 256 & 256 & ND & - \\
\hline 56 & 64 & 1024 & 256 & 64 & 256 & 256 & $\dagger$ & - \\
\hline 63 & 64 & 256 & 256 & 16 & 256 & 256 & $\dagger$ & - \\
\hline 70 & 64 & 16 & 64 & - & 16 & 64 & $\dagger$ & - \\
\hline 77 & 64 & 64 & 64 & 16 & 16 & 64 & $\dagger$ & - \\
\hline 84 & 64 & 64 & 256 & - & 16 & 64 & $\dagger$ & - \\
\hline
\end{tabular}

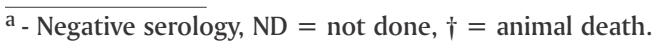

the $49^{\text {th }}$ DPI. These findings corroborate with those reported by Shirahata \& Shimizu (1974) (Cited by Dubey 1986), after intraperitoneal inoculation of swine with $T$. gondii tachyzoites. Since the antibodies were related to chronic infection, the IgG class had the capacity of being active even after later detection (up to the $84^{\text {th }}$ DPI in this study) when compared with immunoglobulin from the IgM class. This class can only be identified up to a few weeks after infection (Silva et al. 2002).

The first report of the isolation of T. gondii in semen is a reference cited by Spence et al. (1978), in which Disko et al. (1971) succeeded in recovering this agent from seminal samples of three out of 125 men with natural toxoplasmic infection. Later, Spence et al. (1978), Teale et al. (1982), and Aganga et al. (1988) working with sheep, Dubey \& Sharma (1980) with goats, and Scarpelli (2001) with cattle obtained positive results in the detection of $T$. gondii in semen of these experimentally infected animals.

This study reports the first description of the isolation of $T$. gondii from the semen of experimentally infected swine. Regarding the different species, strains, inoculum and method of infection, the results obtained from our data on the recovery of the protozoan from seminal samples appear to agree with those authors mainly to the period (Number of days) required to successfully recover $T$. gondii. Spence et al. (1978) inoculated $T$. gondii in two ovine and obtained infected semen on the $20^{\text {th }}$ DPI from one of the animals and on the $20^{\text {th }}$ and $25^{\text {th }}$ from the second animal.

Dubey \& Sharma (1980) isolated T. gondii from goat semen (from $7^{\text {th }}$ to $59^{\text {th }} \mathrm{DPI}$ ), although this is contradictory to other studies. For the detection of T. gondii, these authors based on the positive serology and the presence of a brain cyst in

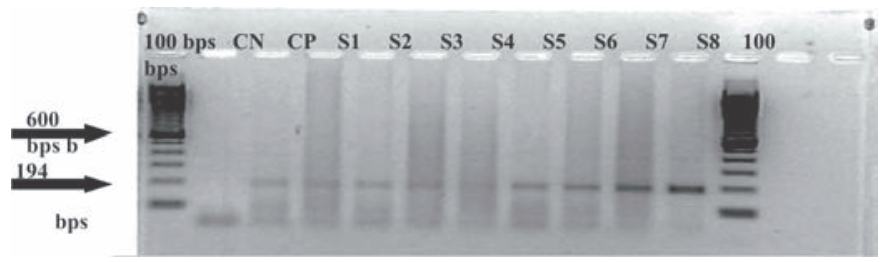

Fig.1. Agarose gel electrophoresis of PCR-amplified products of Toxoplasma gondii DNA.

100bps: molecular marker ladder; CN: Negative control (boar semen); CP: Positive Control (tachyzoites of T. gondii); S1: Serial dilution of $T$. gondii tachyzoites in semen $\left(1 \times 10^{0}\right.$ tachyzoites $\left./ \mathrm{mL}\right)$; S2: Serial dilution of $T$. gondii tachyzoites in semen $\left(1 \times 10^{1}\right.$ tachyzoites $/ \mathrm{mL}$ ); S3: Serial dilution of $T$. gondii tachyzoites in semen $\left(1 \times 10^{2}\right.$ tachyzoites $\left./ \mathrm{mL}\right)$; S4: Serial dilution of $T$. gondii tachyzoites in semen $\left(1 \times 10^{3}\right.$ tachyzoites/mL); S5: Serial dilution of T. gondii tachyzoites in semen $\left(1 \times 10^{4}\right.$ tachyzoites $\left./ \mathrm{mL}\right)$; S6: Serial dilution of $T$. gondii tachyzoites in semen $\left(1 \times 10^{5}\right.$ tachyzoites $\left./ \mathrm{mL}\right)$; S7: Serial dilution of T. gondii tachyzoites in semen $\left(1 \times 10^{6}\right.$ tachyzoites $/ \mathrm{mL}$ ); S8: Serial dilution of T. gondii tachyzoites in semen $\left(1 \times 10^{7}\right.$ tachyzoites $\left./ \mathrm{mL}\right)$.

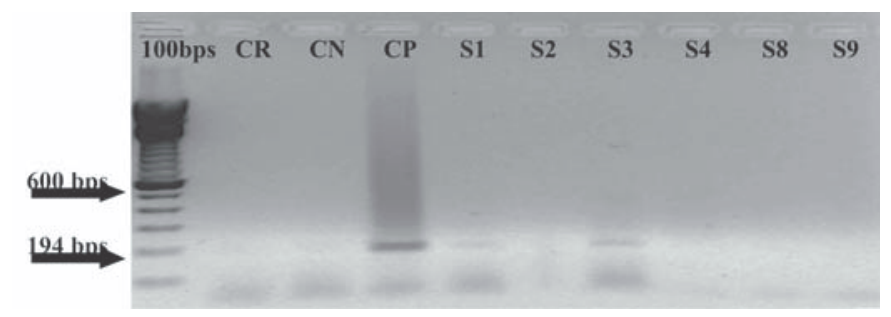

Fig.2. Agarose gel electrophoresis of PCR-amplified products of Toxoplasma gondii DNA from seminal samples of experimentally infected boars.

100bps: molecular marker ladder; $\mathrm{CR}=$ Reaction control $\left(\mathrm{H}_{2} \mathrm{O}\right.$ mili Q); $\mathrm{CN}=$ Negative control (boar semen); $\mathrm{CP}=$ Positive control ( $1 \times 10^{7} \mathrm{~T}$. gondii tachyzoites $/ \mathrm{mL}$ of semen); $\mathrm{S} 1=$ Semen of Boar 1 (84 DPI); S2 = Semen of Boar 2 (84 DPI); S3 = Semen of Boar 03 (84 DPI); S4 = Smen of Bar 4 (84 DPI); S8 = Semen of Boar 8 (84 DPI); S9 = Semen of Boar 9 (84 DPI).

inoculated mice. Teale et al. (1982) and Aganga et al. (1988) isolated $T$. gondii in sheep semen only on the $21^{\text {th }} \mathrm{DPI}$.

In the present study, the isolation of $T$. gondii from swine semen through the bioassays was found in two out of the three inoculated animals with tachyzoites, i.e., in Boar 1 on the $49^{\text {th }}$ DPI, and in Boar 5 on the $5^{\text {th }}$ and $49^{\text {th }}$ DPI. Out of the three swine inoculated with oocysts, only one of them (Boar 3 ) had T. gondii in semen samples on the $3^{\text {rd }}, 49^{\text {th }}$ and $56^{\text {th }} D P I$. The PCR technique detected T. gondii DNA in semen samples analyzed on the $84^{\text {th }}$ DPI for two boars, one infected with tachyzoites (Boar 1) and the other with oocysts (Boar 3). Although the experimental days were not the same for the presence of $T$. gondii in semen samples, the PCR procedure detected protozoan DNA from two out of the three boars with positive bioassays (Fig.1-2).

Data obtained from this study showed that the detection of $T$. gondii in semen samples from inoculated swine was possible by PCR, which has advantages over the traditional methods used to isolate this protozoan. In addition, other reports have shown 


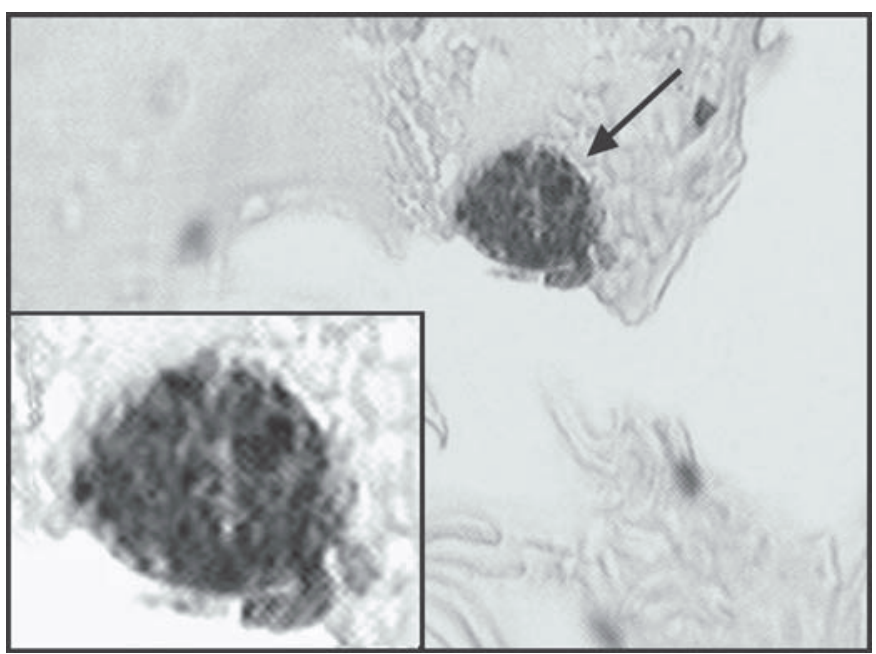

Fig.3. Seminal vesicle of Boar 1, inoculated with $1.0 \times 10^{6}$ tachyzoites of Toxoplasma gondii with positive immunomarket from T. gondii (arrow). Estrepto-avidina-biotina-peroxidase, obj. 40x, detail obj.100x.

a good correlation between PCR results with those found with inoculating mice (Homan et al. 2000). Furthermore, the use of PCR in association with bioassay results for the detection of $T$. gondii in semen samples appears to be a very efficient alternative procedure to diagnose toxoplasmic infections in semen.

Although other DNA sequences from $T$. gondii could also be used for PCR studies (P30, TGR1E, or a region from the $18 \mathrm{~S}$ rRNA), the 194-bp fragment from the $\mathrm{B}_{1}$ gene of $T$. gondii was chosen for amplification because this gene was found to be highly conserved in several isolates and present in at least 35 loci of T. gondii (Fuentes et al. 1996).

The number of positive semen samples for the presence of $T$. gondii found in this study corroborate with data from the literature, even though these studies were conducted with different animal species. Moreover, boars excrete large volumes of seminal fluid $(50-430 \mathrm{~mL})$, and only three $1 \mathrm{~mL}$-aliquot were used for the bioassays and PCR procedures.

The immunohistochemical results revealed the presence of $T$. gondii in the epididymes of two swine (Boar 1 and 2) inoculated with tachyzoites and oocysts, respectively, and in the seminal vesicle of Boar 1 . These findings confirmed the detection of this parasite in the semen of Boar 1 (Fig.3).

The detection of $T$. gondii (bioassays and PCR) in semen and positive immunohistochemical test in epididymes and seminal vesicles of experimentally infected swine suggest the possibility of a sexual transmission of this parasite in this animal species.

Acknowledgments.- This study was conducted with the financial support from FAPESP -Fundação de Amparo à Pesquisa do Estado de São Paulo (Proc.01/ $10643-9,02 / 02812-8,02 / 02813-4$, and 02/02814-0), and partially by the "Centro de Pesquisas em Sanidade Animal” (CPPAR), Faculdade de Ciências Agrárias e Veterinárias, Unesp-Jaboticabal, SP, Brazil.

\section{REFERENCES}

Aganga A.O., Umoh J.U., Kyewalabye E.K. \& Ekwempu C.C. 1988. Comparative experimental transmission studies with Nigerian isolates and TS-I strain of Toxoplasma gondii in sheep. J. Anim. Prod. Res. 8:104-120.
Assadi-Rad A.M., New J.C. \& Patton S. 1995. Risk factors associated with transmission of Toxoplasma gondii to sows kept in different management systems in Tennessee. Vet. Parasitol. 57:289-297.

Camargo M.E. 1964. Improvided technique of indirect immunofluorescence for serological diagnosis of toxoplasmosis. Revta Inst. Med. Trop. São Paulo $6: 117-118$.

Costa A.J., Araújo F.G., Costa J.O., Lima J.D. \& Nascimento E. 1977. Experimental infection of bovines with oocysts of Toxoplasma gondii. J. Parasitol. 63(2):212-218.

Costa A.J. 1982. Reinoculação de Toxoplasma gondii Nicolle \& Manceaux, 1909, em suínos portadores de infecção toxoplásmica experimental. Tese de Livre Docência, FCAV, Universidade Estadual Paulista, Jaboticabal, SP. $105 p$.

Damriyasa I.M., Bauer C., Edelhofer R., Failing K., Lind P., Petersen E., Schares G., Tenter A.M., Volmer R. \& Zahner H. 2004. Cross-sectional survey in pig breeding farms in Hessen, Germany: seroprevalence and risk factors of infections with Toxoplasma gondii, Sarcocystis spp. and Neospora caninum in sows. Vet. Parasitol. 126(3):271-286.

D’Angelino J.L. \& Ishizuka M.M. 1986. Toxoplasmose suína. I. Inoculação experimental com taquizoítos de T. gondii por via intraperitoneal. Bolm Sanit. Panam. 100:400-409.

Disko R., Braveny I. \& Vogel P. 1971. Studies on the occurrence of Toxoplasma gondii in the human ejaculate. Z. Tropenmed. Parasitol. 22(4):391-396.

Dubey J.P. 1986. A review of toxoplasmosis in pigs. Vet. Parasitol. 19:181223.

Dubey J.P. 1994. Toxoplasmosis. J. Am. Vet. Med. Assoc. 205:1593-1598.

Dubey J.P. \& Sharma S.P. 1980. Prolonged excretion of Toxoplasma gondii in semen of goats. Am. J. Vet. Res. 41:794-795.

Dubey J.P. \& Urban J.F. 1990. Diagnosis of transplacentally induced toxoplasmosis in pigs. Am. J. Vet. Res. 58:1295-1299.

Fuentes I., Rodriguez M., Domingo C.J., Castillo F. Del, Juncosa T. \& Alvar J. 1996. Urine sample used for congenital toxoplasmosis diagnosis by PCR. J. Clin. Microbiol. 34:2368-2371.

Gamble H.R. 1997. Parasites associated with pork and pork products. Revue Scient. Techn. 16:496-506.

Giraldi N., Freire R.L., Navarro I.T., Viotti N.M.A., Bueno S.G. \& Vidotto O. 1996. Estudo da toxoplasmose congênita natural em granjas de suínos em Londrina, PR. Arq. Bras. Med. Vet. Zootec. 48:83-90.

Guesdon J. L., Ternynck T. \& Avrameas S. 1979. The use of avidin-biotin interaction in immunoenzymatic techniques. J. Histochem. Cytochem. 27:1131-1139.

Hitt J.A. \& Filice G.A. 1992. Detection of Toxoplasma gondii parasitemia by gene amplification, cell culture and mouse inoculation. J. Clin. Microbiol. 30:3181-3184.

Homan W.L., Vercammen M., De Braekeller J. \& Verschueren H. 2000. Identification of a 200 - to 300 -fold repetitive 529 bp DNA fragment in Toxoplasma gondii, and its use for diagnostic and quantitative PCR. Int. J. Parasitol. 30:69-75.

Jamra L.M.F. \& Vieira M.P.L. 1991. Isolamento do Toxoplasma gondii de exsudato peritoneal e órgãos de camundongos com infecção experimental. Revta Inst. Med. Trop., São Paulo, 33:435-441.

Sabin A.B. 1941. Toxoplasmic encephalitis in children. J. Am. Med. Assoc. 116:801-807.

Sambrook J., Fritsch E.F. \& Maniatis T. 1989. Molecular Cloning: a laboratory manual. 2nd ed. Cold Spring Harbor Laboratory Press, Long Island, NY.

Scarpelli L.C. 2001. Viabilidade da transmissão venérea do Toxoplasma gondii em bovinos. Dissertação de Mestrado, FCAV, Universidade Estadual Paulista, Jaboticabal, SP. 128p.

Silva D.A.O., Silva N.M., Mineo T.W.P., Pajuaba Neto A.A., Ferro E.A.V. \& Mineo J.R. 2002. Heterologous antibodies to evaluate the kinetics of the humoral immune response in dogs experimentally infected with Toxoplasma gondii RH strain. Vet. Parasitol. 107:181-185. 
Silva R.A.M.S., Bonassi C., Dalla Costa O.A. \& Morés N. 2003. Serosurvey on toxoplasmosis in outdoor pig production systems of the southern region of Brazil. Revue Elev. Med. Vet. Pays Trop. 56(3/4):145-147.

Spence J.B., Beattie J., Faulkner L. \& Watson W.A. 1978. Toxoplasma gondii in the semen of rams. Vet. Rec. 102:38-39.

Teale A.J., Blewett D.A., Miller J.K. \& Buxton D. 1982. Experimentally induced toxoplasmosis in young rams: The clinical syndrome and semen secretion of Toxoplasma. Vet. Rec. 111:53-55.
Tenter A.M., Heckeroth A.R. \& Weiss L.M. 2000. Toxoplasma gondii: from animals to humans. Int. J. Parasitol. 30:1217-1258.

Vidotto O. \& Costa A.J. 1987. Toxoplasmose experimental em porcas gestantes. I. Observações clínicas e hematológicas. Arq. Bras. Med. Vet. Zootec. 39:623-639.

Wentz I. \& Bortolozzo L.F. 1998. Inseminação artificial em suínos, p.209-220. In: Sobestiansky J., Wentz I., Silveira P.R.S. \& Sesti L.A.C. (ed.), Suinocultura Intensiva: produção, manejo e saúde do rebanho. Embrapa, Brasília. 